\title{
Taxonomic Study of the Genus Brachybacterium: Brachybacterium nesterenkovii sp. nov.
}

\author{
O. R. GVOZDYAK, ${ }^{1 *}$ T. M. NOGINA, ${ }^{1}$ AND P. SCHUMANN ${ }^{2}$ \\ Institute of Microbiology and Virology, Academy of Sciences of Ukraine, Zabolotnogo 156, Kiev 252143, Ukraine, \\ and Zentralinstitut für Mikrobiologie und Experimentelle Therapie, Jena 6900, Germany ${ }^{2}$
}

\begin{abstract}
A new species, Brachybacterium nesterenkovii, is proposed for a group of coryneform bacteria that were isolated from milk products. These organisms have morphological, biochemical, and chemotaxonomic characteristics that are peculiar to the genus Brachybacterium. In contrast to strains of the only previously described species of the genus, Brachybacterium faecium, the representatives of the new species lack glycine in their peptidoglycan, although the peptidoglycan is of the same general type, and have large amounts of rhamnose in their cells. The strains of $B$. nesterenkovii exhibit no serological relationship with strains of $B$. faecium; in a numerical phenotypic analysis the two species were easily separated and formed clear-cut clusters. DNA-DNA hybridization between the type strains of $B$. faecium and $B$. nesterenkovii showed a level of homology of $22 \%$. Strain 35 (= IMV Ac-752) is the type strain of $B$. nesterenkovii.
\end{abstract}

In their investigation of the cell walls of Arthrobacter spp. strains NCIB 9859 , NCIB $9860^{\mathrm{T}}$ ( $\mathrm{T}=$ type strain), and NCIB 9861, "Micrococcus conglomeratus" CCM 2134 and CCM 2135, Micrococcus luteus CCM 2136 and CCM 2137, and "Staphylococcus lactis"' CCM 2432, Bogdanovsky et al. (7) determined that the peptidoglycan composition and structure are the same for all of these strains but are not typical of the taxa to which the organisms are assigned. According to the classification of Schleifer and Kandler (29), the peptidoglycan of these bacteria is a peptidoglycan of the mesodiaminopimelic acid (DAP)-D-Glu ${ }_{2}$ type (variation A $4 \gamma$ ), which has not been found in any other bacteria. Later, Schleifer and Lang (30) showed that the DNA-DNA hybridization values for these strains are high enough to assume that they belong to one genus. Similarity was also found in their cytochrome patterns. A comparison of the properties of these bacteria with the properties of strains isolated in our laboratory, as well as previously published data, led us to propose a new taxon ("conglomeratus") for them, presumably at the genus level $(23 a, 24)$. Later, the new genus Brachybacterium was proposed for some of these bacteria (11), and the members of the "conglomeratus" taxon were shown to be brachybacteria (25). We have found among the brachybacteria isolated in our laboratory a group of strains which differ from the single previously described species of the genus, Brachybacterium faecium, in a number of characteristics. The aim of this work was to elucidate the taxonomic position of these bacteria.

\section{MATERIALS AND METHODS}

Bacterial strains and culture conditions. Reference strains of B. faecium (originally labeled Arthrobacter spp. strains NCIB 9859 , NCIB $9860^{\mathrm{T}}$, and NCIB 9861) were received from the All-Union Collection of Microorganisms (RSFSR), and $M$. luteus CCM 169 was obtained from the Czechoslovak Collection of Microorganisms. Strains IMV Ac-750, IMV Ac-751, IMV Ac-752 ${ }^{\mathrm{T}}$, IMV Ac-753, and IMV Ac-754 were isolated at the Institute of Microbiology and Virology of the Academy of Sciences of the Ukraine in 1984 from milk products by using the methods described previously (16)

\footnotetext{
* Corresponding author.
}

Working cultures were grown on beef extract agar (BEA) (18) at $28^{\circ} \mathrm{C}$; stock cultures were stored on the same medium at $4^{\circ} \mathrm{C}$. To detect the presence of DAP, cells were grown on BEA slants at $34^{\circ} \mathrm{C}$ for $48 \mathrm{~h}$. To study other chemotaxonomic characteristics, cultures were incubated in 500-ml shake flasks $(240 \mathrm{rpm})$ at $28^{\circ} \mathrm{C}$ and harvested at the exponential growth phase. For menaquinone pattern determinations cells were grown in a medium containing $10 \mathrm{~g}$ of dextrose, $10 \mathrm{~g}$ of peptone, $2 \mathrm{~g}$ of casein hydrolysate, $2 \mathrm{~g}$ of yeast extract, $6 \mathrm{~g}$ of $\mathrm{NaCl}$, and $1,000 \mathrm{ml}$ of tap water $(\mathrm{pH} 7.5)$. Biomass for other chemical analyses was obtained by using beef extract broth supplemented with $1 \%$ glucose and $1 \%$ yeast autolysate.

Morphological and biochemical properties. Cell morphology was studied with Gram-stained smears of cultures grown on BEA (18) at $28^{\circ} \mathrm{C}$ for 14 and 18 to $20 \mathrm{~h}$ and 2 to 10 days; colony morphology was studied with cultures grown on BEA, P agar (23), milk agar (6) and glucose-asparagine agar (2) at the same temperature. Motility, spore formation, tolerance to $\mathrm{NaCl}$, and ability to grow at various temperatures were studied by the methods of Labinskaya (18). Tests for carbohydrate and alcohol oxidation and arginine hydrolysis were performed by the methods of Baird-Parker (3). Utilization of sodium salts of organic acids, reduction of nitrate to nitrite, and starch hydrolysis were determined as described by Gordon and Smith (14). Hydrolysis of tyrosine, xanthine, and hypoxanthine and urease formation were studied by the methods of Gordon and Mihm (13). Hydrolysis of Tween 20, Tween 40, Tween 60 , and Tween 80 was determined as described by Sierra (31). Esculin hydrolysis was determined by the method of Kvasnikov and Nesterenko (17), and acetoin formation was determined by the method of Baird-Parker (4). Gelatin hydrolysis and growth on Simmons citrate agar were determined by the methods of Collins and Lyne (10). Lecitinase formation was determined by the method of Collins (9). Growth on medium containing $20 \mu \mathrm{g}$ of furazolidone per $\mathrm{ml}$ and the ability to oxidize glycerol in the presence of $0.4 \mu \mathrm{g}$ of erythromycin per $\mathrm{ml}$ were studied as described by Baker (5); the ability to ferment glucose was determined by the method of Schleifer (28).

Susceptibility to antibiotics was determined by the disk method (12), using commercial kits with the following antibiotic concentrations: ampicillin, methicillin, and oxacillin, $10 \mu \mathrm{g}$ per disk; rifampin, $5 \mu \mathrm{g}$ per disk; carbenicillin, $25 \mu \mathrm{g}$ 
per disk; oleandomycin and erythromycin, $15 \mu \mathrm{g}$ per disk; polymyxin, $300 \mathrm{U}$ per disk; benzylpenicillin, $10 \mathrm{U}$ per disk; and all other antibiotics, $30 \mu \mathrm{g}$ per disk.

Phenylalanine deaminase, ornithine and lysine decarboxylases, and hydrogen sulfide production were studied by using commercial kits (Indicatory Paper Systems for Complete Identification of Enterobacteria produced by the Enterprise of Bacterial Preparations at the Nizhnij Novgorod Institute of Epidemiology and Microbiology, Nizhnij Novgorod, RSFSR).

Chemotaxonomic characteristics. The presence and form of DAP were determined by ascending paper chromatography (26).

Samples for studying peptidoglycan amino acid composition were prepared by using the method of Schleifer and Kandler (29). The analysis was performed with a model LC-5001 automatic amino acid analyzer (Biotronic, Maintal, Germany), as described previously (27).

Cell monosaccharide patterns were investigated by performing ascending paper chromatography (19).

The presence of mycolic acids was determined as described by Minnikin et al. (22).

Fatty acids were determined as described by Andreev and Galchenko (1), using gas-liquid chromatography.

Menaquinone extraction, purification, and analysis by high-performance thin-layer chromatography and high-performance liquid chromatography on reversed-phase supports were carried out as described previously (15). Menaquinone standards, which were characterized by their mass spectra, were used to identify the extracted menaquinones.

DNA isolation and purification were performed as described by Boháček et al. (8). DNA base composition was determined by using the thermal denaturation method (20) and a model DU-8B (Beckman) spectrophotometer. DNADNA hybridization was carried out by using the membrane filter technique (21). Before labeling by in vitro nick translation (type N.5000 nick translation kit [Amersham]) with $\left[\alpha-{ }^{32} \mathrm{P}\right] \mathrm{dCTP}$, DNA from $B$. faecium NCIB $9860^{\mathrm{T}}$ was treated with restriction endonuclease PstI. Preincubated Hybond $\mathrm{C}$ filters (diameter, $5 \mathrm{~mm}$ ) were loaded with $10 \mu \mathrm{g}$ of unlabeled single-stranded DNA from $B$. faecium NCIB $9860^{\mathrm{T}}$ or Brachybacterium nesterenkovii IMV Ac-752 ${ }^{\mathrm{T}}$ or with $M$. luteus CCM $169^{\mathrm{T}}$ or sea urchin DNA. The ratios of filter-bound DNA to labeled DNA were about 20:1. The preparations were hybridized for $18 \mathrm{~h}$ at $60^{\circ} \mathrm{C}$ in $6 \times \mathrm{SSC}(1 \times$ SSC is $0.15 \mathrm{M} \mathrm{NaCl}$ plus $0.015 \mathrm{M}$ sodium citrate) containing $5 \times$ Denhardt solution, $0.5 \%$ sodium dodecyl sulfate, and $33 \%$ formamide. The radioactivity value obtained for $B$. faecium NCIB $9860^{\mathrm{T}}$ homologous hybrids was defined as $100 \%$ homology; the values for heterologous DNA hybrids were normalized to this value.

\section{RESULTS}

The five strains which we isolated were characterized by using a number of tests, and these organisms had some common properties (Table 1).

In the stationary growth phase the cultures consisted mainly of coccoid cells which were 0.5 to $1 \mu \mathrm{m}$ in diameter. When they were transferred to fresh medium after 14 to $20 \mathrm{~h}$, the cells were round, oval, angular, or short rods that were up to $2 \mu \mathrm{m}$ long. Some cells exhibited V-shaped arrangements.

The cells were gram positive, not acid fast, nonmotile, and nonsporeforming.

Colonies on all of the media which we studied were matte
TABLE 1. Characteristics of $B$. nesterenkovii strains

\begin{tabular}{|c|c|c|c|c|c|}
\hline \multirow[b]{2}{*}{ Characteristic } & \multicolumn{5}{|c|}{ Strains } \\
\hline & $\begin{array}{l}\text { IMV } \\
\text { Ac-750 }\end{array}$ & $\begin{array}{l}\text { IMV } \\
\text { Ac-751 }\end{array}$ & $\underset{\text { Ac- }-752^{\mathrm{T}}}{\operatorname{IMV}}$ & $\begin{array}{l}\text { IMV } \\
\text { Ac-753 }\end{array}$ & $\begin{array}{c}\text { IMV } \\
\text { Ac-754 }\end{array}$ \\
\hline Growth in $5 \% \mathrm{NaCl}$ broth & $+{ }^{a}$ & \pm & - & - & + \\
\hline Xylose & - & + & \pm & \pm & \pm \\
\hline Galactose & - & + & $\bar{t}$ & \pm & $\bar{t}$ \\
\hline Mannose & - & + & - & - & \pm \\
\hline Fructose & + & + & \pm & - & + \\
\hline Lactose & + & + & + & - & + \\
\hline Maltose & - & + & + & + & + \\
\hline D-Melibiose & \pm & \pm & + & - & - \\
\hline Sucrose & - & + & + & \pm & \pm \\
\hline Cellobiose & - & \pm & + & - & - \\
\hline Melezitose & - & \pm & \pm & - & - \\
\hline Raffinose and sorbitol & + & - & - & - & - \\
\hline Starch & - & - & + & + & + \\
\hline Glycerol & + & + & + & \pm & \pm \\
\hline $\begin{array}{l}\text { Utilization of acetate, lactate, } \\
\text { pyruvate, and succinate } \\
\mathrm{NH}_{3} \text { produced from arginine } \\
\text { after: }\end{array}$ & - & - & + & \pm & - \\
\hline 7 days & - & - & - & - & - \\
\hline 21 days & - & + & + & - & - \\
\hline \multicolumn{6}{|l|}{ Hydrolysis of: } \\
\hline Tyrosine & - & \pm & - & - & - \\
\hline Gelatin & - & - & - & - & + \\
\hline Starch & \pm & + & + & + & + \\
\hline \multicolumn{6}{|l|}{ Susceptibility to: } \\
\hline Benzylpenicillin & + & + & + & + & \pm \\
\hline Streptomycin & + & + & + & \pm & + \\
\hline Neomycin & + & + & \pm & + & \pm \\
\hline Kanamycin & - & + & + & + & + \\
\hline Polymyxin & - & \pm & - & - & - \\
\hline
\end{tabular}

$"+$, positive; - , negative; \pm , variable.

${ }^{b}$ Under aerobic conditions.

and convex and had regular edges, and their surfaces were smooth or rough. They were up to $1.5 \mathrm{~mm}$ in diameter (rarely $3 \mathrm{~mm}$ on BEA and P agar). Colonies were lemon yellow on BEA and milk agar, somewhat lighter on $\mathrm{P}$ agar, and pale greyish white on glucose-asparagine agar.

Cultures grew well on BEA, somewhat less well on milk agar and $\mathrm{P}$ agar, and weakly on the glucose-asparagine medium. Cultures grew well in 0 to $0.5 \% \mathrm{NaCl}$ broth and weakly in $5 \% \mathrm{NaCl}$ broth, and no growth was observed in medium containing $7.5 \% \mathrm{NaCl}$. When the organisms were grown in peptone broth, the medium remained transparent or became translucent, and a flaky sediment was formed. As a rule, a growth ring was not observed.

All of the strains which we studied grew well at 18 to $37^{\circ} \mathrm{C}$, fermented glucose, formed acid on glycerol-erythromycin medium, were positive in the test performed with furazolidone, formed acid aerobically from ribose and glucose, hydrolyzed esculin, reduced nitrate to nitrite, and were susceptible to ampicillin, oxacillin, methicillin, carbenicillin, erythromycin, oleandomycin, rifampin, lincomycin, ristomycin, tetracycline, and chloramphenicol. All of the strains were negative for growth on Simmons citrate agar, acid formation from erythrose, arabinose, L-sorbose, rhamnose, trehalose, adonitol, D-arabitol, L-arabitol, and inositol, utilization of oxaloacetate, tartrate, and maleate, phenylalanine deaminase formation, formation of lysine and ornithine decarboxylases, hydrolysis of hypoxanthine, xanthine, urea, Tween 20 , Tween 40 , Tween 60 , and Tween 80 , and produc- 
TABLE 2. Peptidoglycan amino acids and cell monosaccharide patterns of some Brachybacterium strains ${ }^{a}$

\begin{tabular}{|c|c|c|c|c|c|c|c|c|c|}
\hline \multirow{3}{*}{ Strain } & \multicolumn{8}{|c|}{ Peptidoglycan amino acids } & \multirow{3}{*}{$\begin{array}{l}\text { Presence of } \\
\text { rhamnose } \\
\text { in cells }\end{array}$} \\
\hline & \multicolumn{4}{|c|}{ Content $(\mu \mathrm{mol} / \mathrm{mg})$} & \multicolumn{4}{|c|}{ Molar ratio } & \\
\hline & meso-DAP & Ala & Glu & Gly & meso-DAP & Ala & Glu & Gly & \\
\hline IMV Ac-750 & 0.49 & 0.82 & 1.4 & & 1 & 1.7 & 2.85 & & + \\
\hline IMV Ac-751 & 0.41 & 0.69 & 1.3 & & 1 & 1.7 & 3.2 & & + \\
\hline IMV Ac- $752^{\mathrm{T}}$ & 0.36 & 0.66 & 1.19 & & 1 & 1.8 & 3.3 & & + \\
\hline IMV Ac-753 & 0.52 & 0.9 & 1.5 & & 1 & 1.7 & 2.9 & & + \\
\hline IMV Ac-754 & 0.46 & 0.82 & 1.39 & & 1 & 1.8 & 3.0 & & + \\
\hline NCIB 9859 & 1.13 & 2.88 & 3.72 & 1.36 & 1 & 2.1 & 3.3 & 1.2 & - \\
\hline NCIB $9860^{T}$ & 0.30 & 0.73 & 1.08 & 0.39 & 1 & 2.3 & 3.2 & 1.3 & - \\
\hline NCIB 9861 & 0.85 & 1.85 & 2.68 & 1.09 & 1 & 2.2 & 3.2 & 1.3 & - \\
\hline
\end{tabular}

${ }^{a}$ Significant amounts of galactose and glucose are present in the cells of all of the strains tested.

tion of lecithinase, hydrogen sulfide, and acetoin. The results of the other biochemical tests are summarized in Table 1 .

The principal menaquinones of the strains which we studied were nonhydrogenated menaquinones of the MK-7 type. The peptidoglycan lacked glycine, and the amino acid ratios (Table 2) corresponded to a meso-DAP-D-Glu type. The major fatty acids were anteiso- $\mathrm{C}_{15: 0}$ and anteiso- $\mathrm{C}_{17: 0}$. Considerable amounts of galactose, glucose, and rhamnose were found in the cells; mycolic acids were absent. The DNA-DNA homology value for strain IMV Ac- $752^{\mathrm{T}}$, which was considered typical of the strains studied (25), and $B$. faecium NCIB $9860^{\mathrm{T}}$ was $22 \%$. There was no homology between $B$. faecium NCIB $9860^{\mathrm{T}}$ DNA and $M$. luteus CCM $169^{\mathrm{T}}$ DNA $(2 \%)$ or between $B$. faecium NCIB $9860^{\mathrm{T}}$ DNA and sea urchin DNA (0\%). The DNA base composition of strain IMV Ac- $752^{\mathrm{T}}$ was $70 \mathrm{~mol} \% \mathrm{G}+\mathrm{C}$

\section{DISCUSSION}

The studies by Bogdanovsky et al. (7) of the murein peptide components of some strains belonging to the genera Arthrobacter, Micrococcus, and Staphylococcus showed that these strains possess a peptidoglycan of the meso-DAP$\mathrm{D}-\mathrm{Glu}_{2}$ type (variation A $4 \gamma$ ). The amino acids in this peptidoglycan are meso-DAP, alanine, glutamic acid, and glycine in a ratio of $1: 2: 3: 1$ or meso-DAP, alanine, and glutamic acid in a ratio of $1: 2: 3$ (in the latter case the peptide subunits lack glycine amide). Collins et al. (11) recently proposed the new genus Brachybacterium for several strains that were formerly designated Arthrobacter spp. (strains NCIB 9859, NCIB $9860^{\mathrm{T}}$, and NCIB 9861) and were studied previously by Bogdanovsky et al. (7). Until now, this genus has been represented by a single species, $B$. faecium, and the genus is characterized by the following chemotaxonomic features: the peptidoglycan is of meso-DAP-D-Glu type (variation A 4y); the principal menaquinone is MK-7; the principal fatty acids are anteiso- $\mathrm{C}_{15: 0}$ and anteiso- $\mathrm{C}_{17: 0}$; mycolic acids are absent; and the $\mathrm{G}+\mathrm{C}$ content of the DNA is 68 to $72 \mathrm{~mol} \%$ (as determined by the thermal denaturation method). On the basis of these characteristics, the strains isolated in our laboratory should be assigned to the genus Brachybacterium. However, we found some characteristics which distinguish our isolates from B. faecium (Table 2).

All of the strains of $B$. faecium have glycine in their peptidoglycan; this compound is absent from the murein of our isolates. The presence of glycine in the peptidoglycan of $B$. faecium strains correlates with the absence of rhamnose in the cells, whereas in the cells of our isolates significant amounts of this carbohydrate are always detected. Our strains have no serological relationship to representative strains of $B$. faecium (14a). According to the results of a numerical analysis that was based on a considerable number of representatives of the genus Brachybacterium and a wide range of characters, the strains of $B$. faecium and our isolates form two separate clusters (25).

The relationship of our isolates to the genus Brachybacterium, but not to $B$. faecium, was confirmed by the data on DNA-DNA hybridization between the type strain of $B$. faecium and strain IMV Ac-752 ${ }^{\mathrm{T}}$, which is typical of our isolates. A hybridization value of $22 \%$ indicates the relatedness of these organisms at the genus level but not at the subspecies level. This finding agrees with the results obtained by Schleifer and Lang (30) with strain " $S$. lactis" CCM 2432, similar to our strains, and Arthrobacter spp. strains NCIB 9859 , NCIB $9860^{\mathrm{T}}$, and NCIB 9861, which were assigned to the genus Brachybacterium.

On the basis of chemotaxonomic characteristics (Table 3) and DNA homology data, we believe that our isolates should be assigned to a new species of the genus Brachybacterium, for which we propose the name $B$. nesterenkovii.

TABLE 3. Differentiation of species of the genus Brachybacterium

\begin{tabular}{|c|c|c|c|}
\hline \multirow[b]{2}{*}{ Characteristic } & \multirow{2}{*}{$\begin{array}{l}\text { B. faecium } \\
(43 \text { strains })^{a}\end{array}$} & \multicolumn{2}{|c|}{ B. nesterenkovii } \\
\hline & & 5 strains & $\begin{array}{c}\text { IMV strain } \\
\text { Ac- } 752^{T}\end{array}$ \\
\hline $\begin{array}{l}\text { Growth in } 7.5 \% \mathrm{NaCl} \\
\text { broth }\end{array}$ & $83^{b}$ & $0^{b}$ & $-c$ \\
\hline \multicolumn{4}{|l|}{ Acid produced from: } \\
\hline Mannose & 95 & 40 & - \\
\hline Rhamnose & 70 & 0 & - \\
\hline Lactose & 28 & 80 & + \\
\hline Trehalose & 77 & 0 & - \\
\hline Melezitose & 81 & 40 & - \\
\hline Adonitol & 83 & 0 & - \\
\hline D-Arabitol & 98 & 0 & - \\
\hline Gelatin hydrolysis & 81 & 20 & - \\
\hline \multicolumn{4}{|l|}{ Susceptibility to: } \\
\hline Oxacillin & 30 & 100 & + \\
\hline Methicillin & 16 & 100 & + \\
\hline Oleandomycin & 20 & 100 & + \\
\hline $\begin{array}{l}\text { Glycine present in peptide } \\
\text { subunit of peptidoglycan }\end{array}$ & 100 & 0 & - \\
\hline Rhamnose present in cells & 0 & 100 & + \\
\hline
\end{tabular}

$a$ The data for $B$. faecium are for 43 representatives, including strains isolated by us, the type strain, and other reference cultures (25).

${ }^{b}$ Percentage of strains positive.

$c+$, positive; - , negative. 
Description of Brachybacterium nesterenkovii sp. nov. Brachybacterium nesterenkovii (nes. te. ren. ko' vi.i. N.L. gen. n. nesterenkovii, of Nesterenko, named for $\mathrm{O}$. A. Nesterenko, a Ukrainian microbiologist who has made a valuable contribution to the systematics of coryneform and nocardioform bacteria). In the stationary growth phase cells are coccoid (diameter, 0.5 to $1 \mu \mathrm{m}$ ). During the logarithmic growth phase the cells are coccoid, oval, angular, and short rods that vary in size from strain to strain (up to $2 \mu \mathrm{m}$ long). V-shaped cells are observed.

Colonies are matte and convex with regular edges; their surfaces are usually smooth but may be rough. The colony diameter on BEA is up to $1.5 \mathrm{~mm}$ (rarely, $3 \mathrm{~mm}$ ). The color of the colonies is lemon yellow on BEA and milk agar and pale greyish white on glucose-asparagine agar.

Cultures grow well on BEA and somewhat poorly on milk agar, and growth is weak on glucose-asparagine agar. When cultures are grown in peptone broth, the medium remains transparent or becomes translucent, and some flocculent sediment is formed. A growth ring usually is not observed.

Facultatively anaerobic. Gram positive, not acid fast, nonmotile, and nonsporeforming.

Grows well at 18 to $37^{\circ} \mathrm{C}$. Grows on medium containing 20 $\mu \mathrm{g}$ of furazolidone per $\mathrm{ml}$ and forms acid from glycerol in the presence of erythromycin. Does not grow on Simmons citrate agar. Does not tolerate $\mathrm{NaCl}$; grows well in the presence of 0 to $0.5 \% \mathrm{NaCl}$ and weakly in the presence of $5 \%$ $\mathrm{NaCl}$ and does not grow in the presence of $7.5 \% \mathrm{NaCl}$.

Acid is produced aerobically from ribose, galactose, glucose, fructose, maltose, sucrose, and glycerol. Erythrose, arabinose, L-sorbose, rhamnose, trehalose, melezitose, raffinose, adonitol, D-arabitol, L-arabitol, dulcitol, inositol, mannitol, and sorbitol are not attacked. Variable results are observed for acid formation from xylose, mannose, D-melibiose, salicin, and starch. Utilizes tartrate, oxaloacetate, and maleate. Some strains poorly utilize acetate, lactate, pyruvate, and succinate. Phenylalanine deaminase negative and negative for lysine and ornithine decarboxylases. Ammonia production from arginine is detected 21 days after inoculation. Hydrolyzes esculin and starch but not tyrosine, gelatin, xanthine, hypoxanthine, Tween 20 , Tween 40 , Tween 60 , Tween 80 , and urea. Lecithinase, hydrogen sulfide, and acetoin negative.

Susceptible to ampicillin, oxacillin, methicillin, carbenicillin, benzylpenicillin, streptomycin, neomycin, kanamycin, erythromycin, oleandomycin, rifampin, lincomycin, ristomycin, tetracycline, and chloramphenicol. Not susceptible to polymyxin.

Peptidoglycan has meso-DAP, alanine, and glutamic acid $(1: 2: 3)$. There are significant amounts of glucose, galactose, and rhamnose in the cells. Mycolic acids are absent. The principal menaquinone is MK-7. The main fatty acids are anteiso- $\mathrm{C}_{15: 0}$ and anteiso- $\mathrm{C}_{17: 0}$. The $\mathrm{G}+\mathrm{C}$ content of the DNA is $70 \mathrm{~mol} \%$.

Isolated from milk and milk products.

The type strain of $B$. nesterenkovii is strain 35 (= IMV Ac-752).

Additional characteristics of the type strain. B. nesterenkovii IMV Ac-752 ${ }^{\mathrm{T}}$ actively forms acid from D-melibiose, lactose, and starch, weakly oxidizes cellobiose, xylose, and melezitose, and does not attack mannose. Ammonia is formed from arginine within 21 days. Weakly susceptible to neomycin. The $\mathrm{G}+\mathrm{C}$ content of the DNA is $70 \mathrm{~mol} \%$ (as determined by the thermal denaturation method). Other characteristics correspond to those described above for the species.
Differential characteristics of $B$. nesterenkovii and $B$. faecium are shown in Table 3.

\section{REFERENCES}

1. Andreev, L. V., and V. R. Galchenko. 1978. Fatty acid composition and identification of methanotrophic bacteria. Dokl. Akad. Nauk SSSR 239:1465-1468. (In Russian.)

2. Bab'eva, I. P. 1966. Study of soil microorganisms in pure cultures, p. 68-69. In Methods for studying soil microorganisms and their metabolites. Moscow State University, Moscow. (In Russian.)

3. Baird-Parker, A. C. 1963. A classification of micrococci and staphylococci based on physiological and biochemical tests. J. Gen. Microbiol. 30:409-427.

4. Baird-Parker, A. C. 1979. Methods for identifying staphylococci and micrococci, p. 201-210. In F. A. Skinner and D. W. Lovelock (ed.), Identification methods for microbiologists. Academic Press, London.

5. Baker, J. S. 1984. Comparison of various methods for differentiation of staphylococci and micrococci. J. Clin. Microbiol. 19:875-879.

6. Bogdanov, V. M., N. S. Korolyova, and L. A. Bannikova. 1967. Microbiological control on the enterprises of dairy industries. Pishchevaya Promstyshlennost (Moscow) (In Russian.)

7. Bogdanovsky, D., E. Interschick-Niebler, K. H. Schleifer, F. Fiedler, and O. Kandler. 1971. $\gamma$-Glutamyl-glutamic acid, an interpeptide bridge in murein of some micrococci and Arthrobacter sp. Eur. J. Biochem. 22:173-178.

8. Boháček, J., M. Kocur, and T. Martinec. 1967. DNA base composition and taxonomy of some micrococci. J. Gen. Microbiol. 46:369-376.

9. Collins, C. H. 1964. Microbiological methods. Butterworth \& Co., Ltd., London.

10. Collins, C. H., and P. M. Lyne. 1976. Microbiological methods, 4th ed. Butterworth \& Co., Ltd., London.

11. Collins, M. D., J. Brown, and D. Jones. 1988. Brachybacterium faecium gen. nov., sp. nov., a coryneform bacterium from poultry deep litter. Int. J. Syst. Bacteriol. 38:45-48.

12. Egorov, N. S. 1986. Basis of the teaching about antibiotics. Vysshaya Shkola (Moscow) (In Russian.)

13. Gordon, R. E., and J. M. Mihm. 1957. A comparative study of some strains received as Nocardia. J. Bacteriol. 73:15-27.

14. Gordon, R. E., and M. M. Smith. 1953. Rapidly growing acid-fast bacteria. I. Species descriptions of Mycobacterium phlei Lehmann and Neumann and Mycobacterium smegmatis (Trevisan) Lechmann and Neumann. J. Bacteriol. 66:41-48.

14a.Ivshina, I. B. Personal communication.

15. Janke, D., T. Al-Mofarji, G. Straube, P. Schumann, and H. Prauser. 1988. Critical steps in degradation of chloroaromatics by rhodococci. I. Initial enzyme reactions involved in catabolism of aniline, phenol and benzoate by Rhodococcus sp. An 117 and An 213. J. Basic Microbiol. 28:509-518.

16. Kvasnikov, E. I., O. R. Gvozdyak, and V. V. Schkaruba. 1987. Distribution of gram-positive aerobic cocci in the environment. Mikrobiol. Zh. (Kiev) 49:48-51. (In Russian.)

17. Kvasnikov, E. I., and O. A. Nesterenko. 1975. Lactic acid bacteria and the ways of their usage. Nauka, Moscow. (In Russian.)

18. Labinskaya, A. S. 1978. Microbiology with microbiological investigation techniques. Meditsina, Moscow. (In Russian.)

19. Lechevalier, M. P. 1968. Identification of aerobic actinomycetes of clinical importance. J. Lab. Clin. Med. 71:934-944.

20. Marmur, J., and P. Doty. 1962. Determination of the base composition of deoxyribonucleic acid from its thermal denaturation temperature. J. Mol. Biol. 5:109-118.

21. Meyer, S. A., and K. H. Schleifer. 1978. Deoxyribonucleic acid reassociation in the classification of coagulase-positive staphylococci. Arch. Microbiol. 117:183-188.

22. Minnikin, D. E., L. Alshamaony, and M. Goodfellow. 1975 Determination of Mycobacterium, Nocardia and related taxa by thin-layer chromatographic analysis of whole-organism methanolysates. J. Gen. Microbiol. 88:200-204.

23. Naylor, H. B., and E. Burgi. 1956. Observations on abortive 
infections of Micrococcus lysodeikticus with bacteriophage. Virology 2:577-593.

23a.Nesterenko, O. A., E. I. Kvasnikov, O. R. Gvozdyak, Z. P. Vasyurenko, T. M. Nogina, and I. P. Stogny. 1987. Abstr. 2nd Conf. Taxon. Automatic Ident. Bacteria, N70.

24. Nesterenko, O. A., E. I. Kvasnikov, Z. P. Vasyurenko, O. R. Gvozdyak, I. P. Stogny, T. M. Nogina, V. V. Shkaruba, and V. A. Kishchenko. 1986. Biological characteristics of coryneform bacteria with A $4 \gamma$ peptidoglycan variation. Deposited in VINITI 30.IO.86. N 7488-B86. (In Russian.)

25. Nogina, T. M., O. R. Gvozdyak, Yu. S. Sadovnikov, V. V. Shkaruba, and S. L. Kuberskaya. 1991. Phenotypical study and numerical analysis of the strains of coryneform bacteria with A $4 \gamma$ peptidoglycan variation. Mikrobiol. Zh. (Kiev) 53:3-10. (In Russian.)

26. Nogina, T. M., I. P. Stogny, O. R. Gvozdyak, O. A. Nesterenko, and E. I. Kvasnikov, 1987. Rapid method of diaminopimelic acid determination in bacterial cells. Mikrobiol. Zh. (Kiev) 49:98100. (In Russian.)
27. Nogina, T. M., L. D. Varbanets, O. A. Nesterenko, I. P. Stogny, O. R. Gvozdyak, and V. A. Kishchenko. 1989. Amino acid composition of peptidoglycans obtained by different methods from coryneform bacteria cells. Mikrobiol. Zh. (Kiev) 51:16-19. (In Russian.)

28. Schleifer, K. H. 1981. Die Klassifikation von Staphylococcus und Micrococcus. Ein Beispiel für die moderne Bakteriensystematik. Forum Mikrobiol. 4:272-274.

29. Schleifer, K. H., and O. Kandler. 1972. Peptidoglycan types of bacterial cell walls and their taxonomic implications. Bacteriol. Rev. 36:407-477.

30. Schleifer, K. H., and K. Lang. 1980. Close relationship among strains of Micrococcus conglomeratus and Arthrobacter species. FEMS Microbiol. Lett. 9:223-226.

31. Sierra, G. 1957. A simple method for the detection of lipolytic activity of microorganisms and some observations on the influence of the contact between cells and fatty substrates. Antonie van Leeuwenhoek J. Microbiol. Serol. 23:15-22. 